再発乳癌と直腸癌に併発し, 術前診断が困難であった 直腸 MALT リンパ腫の 1 例

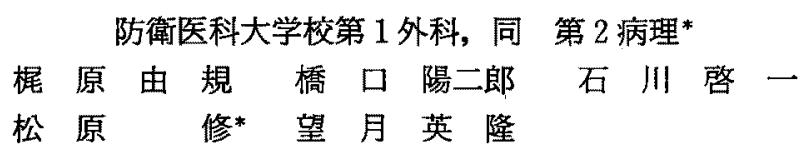

症例活64歳，女性．主訴は便柱狭小，両側異時性乳癌の手術歴有り。近医にて直腸腫 瘤を指摘され, 手術目的にて入院. 入院時, 左胸水貯留を認め, 胸水穿刺吸引細胞診に て class V. 骨シンチにて右第 9 助骨に集積を認め乳癌の再発転移の併存と考えられた. 注腸検查, 大腸内視鏡検查にて直腸の 3 力所 $(\mathrm{Rs}=$ 病変 $1 . R \mathrm{Ra}=$ 病変 $2 . \mathrm{Rbp}=$ 病変 3$)$ に腫瘤を認め, 生検にて病変 1 は高分化腺癌, 病変 2,3 は腫瘍成分を認めず生検を繰 り返したが確定診断は得られなかった. そこで病変 1 の直腸癌に対し, 高位前方切除術 施行 (病理所見 : 1 型, mod, ss, ly1, v1, n0). 同時に病変 3 に対し経肛門的切除生検 を施行. 病理組織所見にて extranodal marginal zone B-cell lymphoma, MALT type の診断を得た．患者の希望にて追加切除は行わず, 病変 2 と 3 には放射線療法 (40Gy) を施行し、いずれも消失をみた。再発乳癌に対しては経口 tamoxifen 投与を施行しつつ 経過観察中である。

索引用語：直腸腫瘤, MALT リンパ腫, 大腸癌合併

\section{緒 言}

大腸の悪性リンパ腫は全消化管の悪性リンパ腫の $10 \sim 15 \%$, 全大腸原発性覀性腫瘍の0.1〜0.6\% と稀な 疾患である ${ }^{12)}$. 今回, われわれは異時性両側性乳癌再 発, 直腸癌に併発し, 診断・治療法選択に苦慮した直 陽 mucosa-associated lymphoid tissue (MALT) リ ンパ腫を経験したので報告する。

$$
\text { 症例 }
$$

患者：64歳，女性.

主訴: 脱肛, 便柱狭小.

家族歴：特記すべき事項なし。

既往歴：23歳時, 卵巣基腫にて变腫核出術. 43歳時, 左乳癌にて左乳房切除術. 47歳時, 子宮筋腫にて単純 子宮全摘術. 50 歳時, 右乳癌にて右乳房切除術.

現病歴: H12年 9 月より主訴が出現し, 近医にて注 腸造影, 大腸内視鏡検查を施行したところ, 直腸の 3 力所に腫瘤 $(\mathrm{Rs}=$ 病変 $1 . \mathrm{Rab}=$ 病変 $2 . \mathrm{Rbp}=$ 病変 3$)$

2002 年12月 2 日受付 2003 年 1 月 29 日採用

〈所属施設住所〉

₹359-8513 所沢市並木 $3-2$
を指摘された，H12年11月29日当院紹介受診. 精査・治 療目的にて12月21日入院となった。

入院時現症：直腸診にて病変 1 は触知せず．病変 2 は肛門縁より $6 \mathrm{~cm}, 9$ 時方向に径 $1 \mathrm{~cm}$ 大の平滑な隆 起性病変として触知。病変 3 は肛門縁より $3 \mathrm{~cm}$, 後壁 に半周性の不整な隆起性病変として触知した，体表り ンパ節哇触知しなかった。

血液生化学的検査 : NCC $-\mathrm{ST}-439 \not 5270 \mathrm{U} / \mathrm{ml}$ と上 昇. 他に異常所見を恝めず。

胸部単純 $\mathbf{X}$ 線検查：左肺野儿胸水貯留.

胸部 CT 検查 : 左胸水貯留を認めた. 肺門部リンパ 節腫大など，その他の病変は認めず.

左胸水穿刺吸引細胞診 : class V, 乳癌由来のadenocarcinoma の猃断を得た.

骨シンチ：右第 9 助骨に集積像を認め, 乳癌の骨転 移再発と考えられた。

注晹造影検査：Rs に径 $2 \mathrm{~cm}$ 大の隆起性の病変 1 , $\mathrm{Rab}$ に径 $1 \mathrm{~cm}$ 大の隆起性の病変 $2, \mathrm{Rbp}$ 後壁主体半 周性に不整な隆起性の病変 3 を認めた（図 1，2）。

大腸内視鏡検査：病変 1 は肛門緑より $10 \mathrm{~cm} に 1 /$ 4 周性 1 型腫湯として認め, 生検にて well differ- 


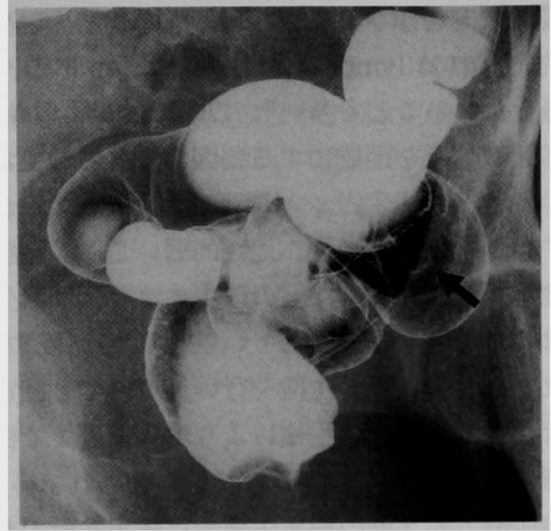

図 1 注腸造影検查所見 (1)：Rsに径 2 $\mathrm{cm}$ 大の隆起性病変 1 （矢印）を認めた。

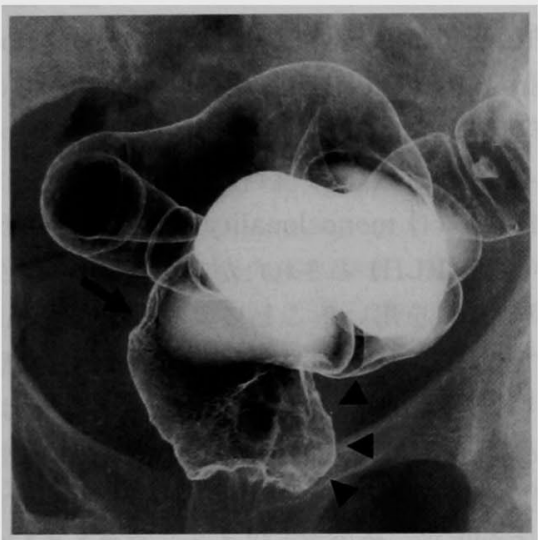

图 2 注晹造影検查所見（2）：Rabに径 1 $\mathrm{cm}$ 大の隆起性病変 2 (矢印), $\mathrm{Rbp}$ 後壁主 体に半周性の不整な隆起性病変 3 (矢頭) を認めた。

entiated adenocarcinoma $の$ 診断を得た。病変 2 は肛 門緑より $6 \mathrm{~cm}$ に径 $1 \mathrm{~cm}$ 大の粘膜下腫瘤として認め (図 3 )，病変 3 は曾状線直上に $2 / 5$ 周性の不整形隆 起腫瘤として認め(図 4), 病変 2,3 とも生検では再 生性上皮のみであるが，大型の異型リンパ球が少数散 見され悪性リンパ腫も否定できないとの診断であっ た。

股部 CT, MRI：Rb 後壁主体に造影奻果を示す径 3 $\mathrm{cm}$ 大の腫留性病変を認めた。

入院後経過：病変 3 について H13年 1 月11日, 直腸 鏡下粘膜下生検を施行した。病理組織所見では粘膜脱 症候群に矛盾しないとされたが，乳癌転移の可能性も

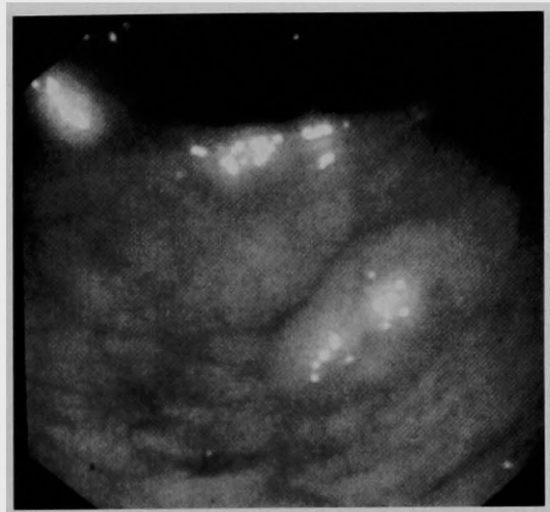

図 3 大腸内視鏡検查所見（1）：肛門縁よ り $6 \mathrm{~cm}$ に径 $1 \mathrm{~cm}$ 大の粘膜下腫湺として 病変 2 を認めた。

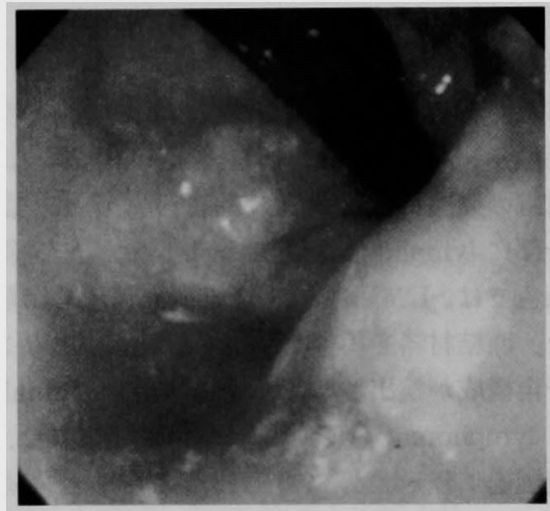

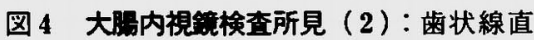
上に 2 / 5 周性の不整形隆起腫瘤として病 変 3 を認めた。

含め，悪性新生物を疑い，確定診断を得るため，1月 26日, 腰椎麻酔下に病変 2,3 に対し経肛門的切除生 検を施行した，両病変とも粘膜から粘膜下層にかけて 肧中心を伴う密なリンパ球の增殖が認められたが lymphoepithelial lesion は認められず，また，パラフ イン切片を用いた検索でも免疫グロブリン重鎖遗伝子 再構成が検出されなかったため反応性りンパ増生と診 断された。そこて 2 月16日，病変 1 の直腸癌に対し， 高位前方切除術を施行し，同時に病変 3 に対し再び経 肛門的切除生検を施行した。

摘出標本所見：（病変 $1 ） \mathrm{Rs}$ に径 $2.0 \times 2.4 \mathrm{~cm}$ 大の 1 型の腫痬を認めた。

病理組織学的所見：(病変 1) Rs, type 1, mod, ss, lyl, v1, n0, ow (-), aw (-), ew (-), stage II 


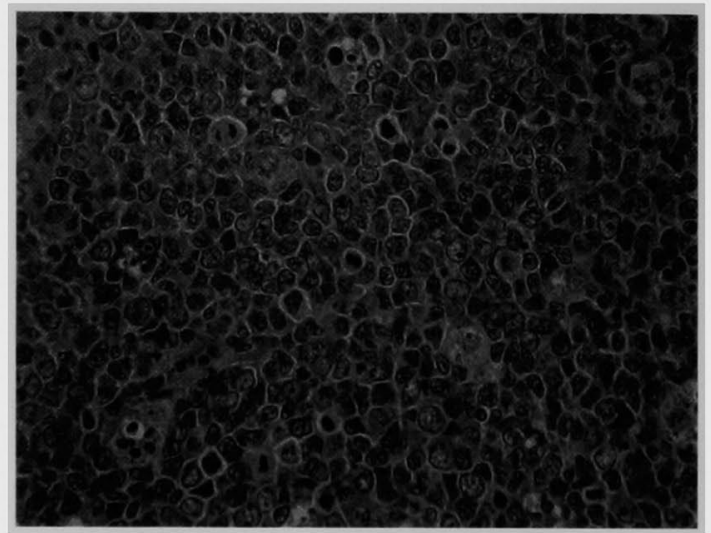

図 5 病理組織学的所見：核に軽度のくびれのある小型 から中型異型リンパ球 (centrocyte-like cell) が反応性 リンパ沟胞の周曲に浸潤增殖する像が認められた ( $\mathrm{HE} \times 400)$

であった（病変 3 )核に軽度のくびれのある小型から 中型異型リンパ球（centrocyte-like cell）が反応性リ ンパ滤胞の周囲に浸潤增殖する像が認められ（図 5), ごく一部に lymphoepithelial lesion の形成を認めた。 免疫染色では, L26陽性, CD5, CD10, UHCL1陰性で あった. 凍結材料を用いた㭘索で免疫グロブリン重鎖 遭云子再構成が検出され, extranodal marginal zone B-cell lymphoma, MALT type と診断された。

術後経過：経過良好にて H13年 3 月 9 日に退院と なった，患者の希望および全身的な乳癌の再発をきた している病状を考虑し, 病変 2 および 3 への追加切除 は行わず，退院後に放射線療法 (40Gy) を施行した。 放射線照射 12 力月後の大腸内視鏡検查で，病変 2 , 3 とも消失し, MALT リンパ腫を㒛めなかった。再発 乳癌に対しては経口 tamoxifen (20mg/day) を投与し つつ経過観察中である。

\section{考察}

MALT リンパ腫はIsaacson ら¹4によって1983年 に初めて提唱された疾患概念である。腸型 MALTリ ンパ腫の特徵としては, 肉眼所見として通常, 単発, または多発の粘膜下腫瘍様の隆起性病変を呈すること が多いとされている゙!.本症例では病変 2 はMALT リ ンパ腫として典型的な肉眼所見を示していたが，病変 3 については 3 型腫場様の肉眼所見を呈した稀なもの であった。

病理所見の特徴としては, 胃型の MALT リンパ腫 が表層拡大を示すのに対し，腸型では粘膜下層以下に
強い浸潤傾向を示すことが多く，MALT リンパ尰に 特徵的とされる lymphoepithelial lesion はごく軽度 か認められないことも多い5).このことが腸型 MALT リンパ腫の診断を困難にする要因の一つとしてあげら れる.また, MALT リンパ腫は, 生検採取組織が挫堿 しやすいこと，細胞異型が比較的弱いこと，粘膜全層 の観察ができないことなどの理由により，初回生検診 断能は $45 \%$ 程度と報告されている6).このため, 本症が 疑われる場合は頻回の生検を行い，それでも確定診断 困難な場合は部分切除生㭘により粘膜下層まで採取さ れた標本で病理診断を行うことが奖励されている゙． 今回の症例でも 2 回の鉗子生検では確定診断できず, 切除生検も第 2 回目によってようやく確定診断を得 た。

現在最も信頼性の高いMALT リンパ腫の確定診断 の方法としては IgH 遗伝子再構成の monoclonality の証明があり, PCR 法ではパラフィン切片からの検索 も新鲜凍結標本と同様に可能であるとされている8. しかし, 本症例では, 1 度目の切除生検のパラフィン 切片材料からは monoclonality は検出できず反応性 リンパ楛胞（RLH）とされたが， 2 度目の切除生検て 新鮮凍結材料を用いることにより monoclonality を 証明することができた．原因として PCR 法の感度の 低さがあげられる，すなわち，今回の検索は Fr-3 primerのみによって行ったが, この方法での陽性率は

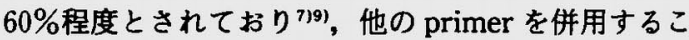
とにより $90 \%$ 近い検出率を得ることができるとの報告 があり ${ }^{10)}$ ，今後改良の余地があると思われた。

大腸悪性リンパ腫全体の 5 年生存率は $41.6 \%$ である が，低悪性度の大腸 MALT リンパ腫の 5 年生存率は $70.8 \%$ との報告"2があり，比較的予後良好とされてい る。このため，本症例ては再発乳癌が患者の予後を規 定する可能性が高いものと考え，患者の希望もあり積 極的な追加切除は行わず，放射線療法のみにて経過観 察を行っている，直腸 MALT リンパ腫に対する照射 例の報告は検索しえなかったか，近年, Stage I・IIの MALT リンパ腫では放射線療法にて非常に有効な局 所コントロールが得られ，5年生存率93〜 96\%，無再 発生存率75〜 76\% ${ }^{111212)}$ との報告がみられる.特に胃, 甲

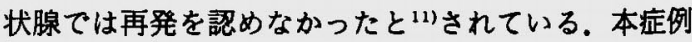
においても，良好な局所制御を得られており，直腸病 変に対しても有効である事が示唆された。

結箈

今回われわれは乳癌再発，直腸癌に併発し術前診断 
が困難であった直腸 MALT リンパ腫の 1 例を経験し た. MALTリンバ腫の鉜子生検湆断は困難であり，下 部直腸病変については経肛門的切除生検わよび新鮮凍 結標本によるmonoclonalityの検出が有用と思われた。 本論文の要旨は第56回大腸肛門病学会総会にて発表した。

\section{文献}

1) Shepherd NA, Hall PA, Coates PJ, et al : Primary malignant lymphoma of the colon and rectum. A histopathological and Immunohisto. chemical analysis of 45 cases with clinicopath. ological correlation. Histopathology 12 : 235-252,1998

2）岩下明徳，竹下盛重，竹村 憕地：原発性大腸覀 性リンパ腫の臨床病理学的榆索. 胃と䁑 $30: 869$ $-886,1995$

3) Isaacson $P$, Wright $\mathrm{DH}$ : Malignant lymphoma of mucosa associated lymphoid tissue- $\mathrm{A}$ dis tinctive type of $B$-cell type. Cancer $52: 1410$ 1416,1983

4) Isaacson $\mathrm{P}$, Wright $\mathrm{DH}$ : Extranodal malignant lymphoma arising from mucosa-associated lymphoid tissue. Cancer $53: 2515-2524,1984$

5）中村栄男, 中村常哉, 谷田部恭他：MALT リンパ 腫の病理。胃と腸 $33: 271-280,1998$

6) 中村常哉, 中村栄男：MALT-type lymphoma $の$ 内視鏡像と病理診断の現況. Gastroenterol En- dosc $42: 1163-1176,2000$

7）赤松泰治, 宮林秀晴, 藤森一也他：胃 MALTリン パ腫と反応性リンパ腫の鑑別診断に関する検討. 胃と缰 $34: 75-81 ， 1996$

8) Wan JH, Trainor $\mathrm{KJ}$, Brisco MJ, et al : Monoclonality in B cell lymphoma detected in paraffin wax embedded sections using the polymerase chain reaction. J Clin Pathol 43: 888-890, 1990

9) Ling FC, Clarke CE, Corbett WEN, et al : Sensitivity of PCR in detecting monocronal $B$ cell proliferations. J Clin Pathol 46:624-627, 1993

10) Diss $T C$, Peng $H$, Wotherspoon $A C$, et al: Detection of monoclonality in low-grade $\mathrm{B}$ cell lymphomas using the polymerase chain reaction is dependent on primer selection and lymphoma type. J Pathol $169: 291-295,1993$

11) Tsang RW, Gospodarowicz MK, Pintilie M, et al : Stage I and II MALT lymphoma: Results of treatment with radiotherapy. Int $\mathrm{J}$ Radiat Oncol Biol Phys 50:1258-1264, 2001

12) Hitchcock S, Andrea K, Fisher DC, et al: Treatment outcome of mucosa-associatd lymphoid tissue/Marginal zone non-Hodgkin's lymphoma. Int J Radiat Oncol Biol Phys 52 : $1058-1066,2002$

\title{
A CASE OF MALT LYMPHOMA OF THE RECTUM WITH SYNCHRONOUS RECTAL CANCER AND SYSTEMIC SPREAD OF RECURRENT BILATERAL BREAST CANCER
}

\author{
Yoshiki KAJIWARA, Yojiro HASHIGUCHI, Keiichi ISHIKAWA, \\ Osamu MATSUBARA* and Hidetaka MOCHIZUKI \\ Department of Surgery 1, National Defence Medical College \\ * Department of Pathology 2, National Defence Medical College
}

We experienced a case of mucosa-associated lymphoid tissue (MALT) lymphoma of the rectum with synchronous rectal cancer and systemic spread of recurrent bilateral breast cancer. Three rectal lesions were detected by colonoscopy in a 64-year-old woman, who had previously undergone bilateral mastectomy. Chest radiography, an aspiration biopsy of pleural effusion, and bone scintigraphy indicated systemic spread of recurrent breast cancer. Barium enema and colonoscopy showed 3 rectal tumors (Rs $=$ lesion $1, \mathrm{Rab}=$ lesion $2, \mathrm{Rbp}=$ lesion 3). Lesion 1 was diagnosed as a well-differentiated adenocarcinoma by biopsy. Reliable diagnoses could not be obtained from repeated biopsies of lesions 2 and 3 . High anterior resection for lesion 1 (moderately differentiated adenocarcinoma, type I, ss, lyl, vl, n0, and stage II), and transanal incisional biopsy of lesion 3 were done. The resected specimen was histopathologically diagnosed as an extranodal marginal zone B-cell lymphoma MALT. Considering the advanced status of breast cancer and the patient's preference, no additional resection was done but radiotherapy (40 Gy) was conducted for the remaining MALT lymphoma. Oral tamoxifen was administered for recurrent breast cancer and the patient has since been carefully followed up. 